\title{
Study on Major Parasitic Problems of Rural Cattle in and Around Ambo, Western Oromia, Ethiopia
}

\author{
DINKA, A*, BEDADA BUTA,YACOB, H.T
}

Faculty of Veterinary Medicine, Addis Ababa University, P.O.Box 34, Debre Zeit, Ethiopia

*Corresponding author: dinka_ayana@yahoo.com

\section{SUMMARY}

The study was conducted in and around Ambo, West Shoa zone of Oromia regional state, from November 2007 to April 2008 with the aim of determining the prevalence of major parasitic problems and identification of those parasites parasitizing rural cattle of the area. Fecal examination was performed using qualitative techniques (Flotation and sedimentation) on 352 cattle and simultaneously skin scrapings and blood smears were prepared for examination of suspected cases of ecto parasites and haemoparasites respectively. Accordingly, $49 \%$ over all prevalence of endo parasites was registered. The endoparasites identified were Fasciola hepatica (23\%), Toxocara vetulorum $(9.66 \%)$, Paraphistomum cervi $(9.38 \%)$, Strongyle spp (4.83\%), Monezia benedeni (0.85\%). $0.57 \%$ prevalence of Babesia bovis was also recorded. The over all prevalence of ectoparasites was found to be $24 \%$. The common ectoparasites identified were Linognathus (1.14\%), Psoroptes bovis (1.4\%), Sarcoptes scabiei $(0.57 \%)$, Amblyomma variegatum $(5.40 \%)$, Hyalomma truncatum (1.14\%) and Boophilus decoloratus (3.4\%). Statistically, significant variation $(P<0.001)$ was observed in the prevalence of Toxocara vetulorum among the age groups of the study animals. These findings suggest the importance of parasitic problems in rural cattle of Ambo and its surrounding which require serious attention by concerned bodies to minimize and control the effects of those parasites on the general health status, productivity and reproductive potential of cattle.

Key Words: Ambo, cattle, parasites, Prevalence

\section{INTRODUCTION}

The growing demand for meat and milk in developing world, changing functions of livestock and changing consumers perspectives are the major driving forces in the global livestock sector during the next two decades (World Bank, 2001)). The movement of people from rural areas to urban centers will increase the demand for food of animal origin. By the year 2020 the global population is projected to consume about 120 million tons of meat and 220 million tons of milk above the current consumption (World Bank, 2001, Ibrahim and Olaloku, 2000). Ethiopia has the largest livestock inventories in Africa, including more than 38 million cattle, 30 million small ruminants, more than one million camels and 4.5 million Equines and 40 million chickens with livestock ownership currently contributing to the lively hood of an estimated 80 percent of the rural population (CSA, 2004).

A number of parasitic, bacterial, fungal and viral diseases and nutritional deficiencies that are prevalent in Ethiopia affect the productivity of cattle (Etsehiwot, 2004). Parasitic diseases of production animals are distributed in the world. In the developed world the greatest component of the impact is probably related to the cost incurred to control these diseases. In developing world, the greatest impacts of these diseases are productivity losses (Eysker and Ploger, 2000). The effect of parasitism can be categorized in to two groups; sub clinical (asymptomatic) and clinical parasitism. The sub clinical effects include losses in animal productivity such as milk production and reduced weight gain. Whereas visible diseases symptoms like diarrhea, skin damage, anemia and associated edema are clinical effects (Eysker and Ploger, 2000).

There is no adequate information regarding 
the prevalence and economic significance of GIT parasites (helminthes and protozoa) and ectoparasites in cattle in the country. The economic assessment of impact of parasites on the performance of livestock is based on the prevalence of such diseases (Grabber, 1975). The effects of internal parasites on cattle vary with the severity of infection as well as age and stress level of animals. In general calves are immunologically incompetent and special sensitivity to handling their first exposure to pasture (Tizard, 1996, Nesru, 1998).

The studies conducted in different parts of the country have revealed the prevalent nature of ectoparasitism (Endale, 2006) and GIT parasitism (Etsehiwot, 2004, Ademe, 1985, Zerfu, 1991)) in bovine species. Ticks are the most important ectoparasites of livestock in tropical and subtropical areas, and are responsible for sever economic losses both through the direct effects of blood sucking or indirectly as vectors of livestock diseases. This study is therefore, initiated to identify and determine the prevalence of parasites affecting cattle.

\section{MATERIALS AND METHODS}

The study was conducted in and around Ambo which is located at about $105 \mathrm{~km}$ West of Addis Ababa. The study area is situated at latitude of $8^{\circ} 47^{\prime}$ to $9^{\circ} 20^{\prime} \mathrm{N}$ and longitude of $37^{\circ} 32^{\prime}$ to $38^{\circ} 3^{\prime} \mathrm{E}$. The altitude of the area is1900 to 2275 meters above sea level and receives an annual rainfall of 800 to $1000 \mathrm{~mm}$ with mean temperature of $19.5^{\circ}$ C.

The study area constitutes, 23\% high land, $60 \%$ mid altitude and $17 \%$ low land. The agricultural scenario is dominated by mixed crop livestock farming system in which crop production system dominates. There are about 211,606 cattle, 48,951 sheep, 32,154 goats, 16,928 horses, 18,569 donkeys, 684 mules, and 138,156 poultry and 15,145 bee colonies (CSA, 2004).

The study included both male and female local breed cattle categorized into 3 age groups: from birth to six months, more than six months to one year and above one year of age. Faecal samples were collected directly from the rectum or top layers of fresh faeces and kept in plastic containers and labeled. After collection, samples were transported in ice box to Parasitology laboratory for investigation. Those samples, which were not examined within 24 hours, were stored in a refrigerator at $4^{\circ} \mathrm{C}$. During collection of samples, approximate or exact age of cattle, housing condition, sex and recent dewoming history were recorded. Fecal samples were processed and examined by flotation and sedimentation techniques as described by (Urquhart et al., 1996) and parasitic eggs were identified using ova identification keys provided by (Soulsby, 1986).

Blood samples were collected from the ear vein and thin smears were prepared and stained with Giemsa stain and examined under the microscope using oil immersion.

While collecting feces, the skins of cattle were inspected for the presence of ectoparasites or skin lesions. Any visible ectoparasite was collected and skin scrapings were made when suspected mange lesions were encountered. Ticks were removed carefully and gently in horizontal pull to the body surface by hand and then preserved in properly labeled plastic containers containing 70\% ethanol. The ectoparasites encountered were identified based on the procedures described by (Soulsby, 1986). Post mortem examination was conducted at Ambo slaughter house using visual inspection, palpation and systemic incision of organs to look for any adult parasites.

\section{Data analysis}

Pearson chi-square $\left(\mathrm{x}^{2}\right)$ test using Inter coded STATA (Version 7.0) soft ware was used to analyze the data. A statistically significant association between the variables and the infections was considered to exist if the calculated P-value is less than 0.05 at $95 \%$ confidence interval.

\section{RESULTS}

A total of 352 cattle were examined for helminthes, protozoa and external parasites. The over all prevalence of endoparasites was found to be $49.48 \%$. 
Among the major parasites identified in cattle, Fasciola hepatica (23.30\%) were the dominant helminthes followed by Toxocara vitulorum (19.66\%), Paraphistomum cervi (9.38\%), Strongyle (4. 83\%), Monezia benedeni (0.85\%) (Figure1). Babesia bovis $(0.57 \%)$ was the only haemoparasite encountered during the study.

Significance difference ( $(\mathrm{P}>0.05)$ was not observed in the prevalence of endo parasites between the different age groups of cattle except T. vitolurum (Table I).

There was no significant difference $(\mathrm{P}>$ 0.05) observed in the prevalence of endoparasites between the sexes of animals (Table I).

Out of 99 cattle examined by post mortem investigation, $11(11.11 \%), \quad 15(15.15 \%)$, 22(22.2\%) were found to harbor Fasciola hepatica, Paraphistomum cervi and Hydatid cyst respectively (Table II).

The over all prevalence of ectoparasites was found to be $28.06 \%$. The predominant ectoparasites identified in the study area were: Linognathus vituli (11.08\%), Amblyomma variegatum (5.40\%), Boophilus decoloratus (3.41\%), Hyalomma truncatum (1.14\%) and Haematopinus eurysternus (1.14\%), Psoroptes bovis (1.14) and Sarcoptes scabiei $(0.57 \%)$ (Figure1). No significant difference $(\mathrm{p}>0.05)$ was observed in the prevalence of ectoparasites between sexes and among the age groups (Table III).

Table I: Prevalence of endoparasites by age and sex group

\begin{tabular}{|c|c|c|c|c|c|c|}
\hline \multirow[b]{2}{*}{$\begin{array}{l}\text { Age groups } \\
\text { of animal }\end{array}$} & \multirow[b]{2}{*}{ No examined } & \multicolumn{5}{|c|}{ No. \& \% of infected animals with endo parasites } \\
\hline & & $\begin{array}{l}\text { T.vetulorum } \\
P=0.000^{*}\end{array}$ & $\begin{array}{l}\text { Fasciola } \\
\text { hepatica } \\
P=0.631\end{array}$ & $\begin{array}{l}\text { Paraphistomum } \\
\text { cervi } P=0.898\end{array}$ & $\begin{array}{l}\text { Monezia } \\
\text { bendeni }\end{array}$ & Mixed \\
\hline$<6$ month & 16 & $6(37.50 \%)$ & $3(18.75 \%)$ & $1(6.25 \%)$ & - & \\
\hline$>6-12$ month & 34 & $6(17.65 \%)$ & $6(17.65 \%)$ & $3(8.82 \%)$ & - & \\
\hline$>12$ moths & 302 & $22(7.28 \%)$ & $73(24.17 \%)$ & $29(9.60 \%)$ & $3(0.99 \%)$ & $6(1.70 \%)$ \\
\hline Sex group & & & & & & \\
\hline Male & 181 & $10(5.52 \%)$ & $39(21.55 \%)$ & $16(8.84 \%)$ & $3(1.66 \%)$ & - \\
\hline Female & 171 & $7(4.09 \%)$ & $43(25.15 \%)$ & $17(9.94 \%)$ & - & - \\
\hline Total & 352 & $34(9.66 \%)$ & $82(23.30 \%)$ & $33(9.38 \%)$ & $3(0.85 \%)$ & $6(1.46 \%)$ \\
\hline
\end{tabular}

* Significant difference between age group but no significant difference between sexes

Table II: Prevalence of endo parasites observed during postmortem examination of adult cattle

\begin{tabular}{|l|l|l|l|}
\hline \multirow{2}{*}{ No. examined } & \multicolumn{3}{|c|}{ No. and \% of infected animals } \\
\cline { 2 - 4 } & Fasciola hepatica & Paraphistomum cervi & Hydatid cyst \\
\hline 10 & $2(20.00 \%)$ & $1(10.00 \%)$ & $3(30.00 \%)$ \\
89 & $9(10.11 \%)$ & $14(15.73 \%)$ & $19(21.35 \%)$ \\
99 & $11(11.11 \%)$ & $15(15.15 \%)$ & $22(22.22 \%)$ \\
\hline
\end{tabular}


Table III: Prevalence of Ectoparasites by Age and sex groups

\begin{tabular}{|c|l|l|l|l|l|l|l|l|l|}
\hline Age Group & $\begin{array}{l}\text { No } \\
\text { examined }\end{array}$ & \multicolumn{7}{|c|}{ No \& infected Animals with different ecto parasites } \\
\hline & & $\begin{array}{l}\text { Psoroptes } \\
\text { bovis }\end{array}$ & $\begin{array}{l}\text { Sarcoptes } \\
\text { scabiei }\end{array}$ & $\begin{array}{l}\text { Linognathus } \\
\text { vituli }\end{array}$ & $\begin{array}{l}\text { Haemotopinus } \\
\text { eurysternus }\end{array}$ & $\begin{array}{l}\text { Hyalomma } \\
\text { truncatum }\end{array}$ & $\begin{array}{l}\text { Amblyomma } \\
\text { variegatum }\end{array}$ & $\begin{array}{l}\text { Boophilus } \\
\text { decoloratus }\end{array}$ & Mixed \\
\hline$<6$ months & 16 & - & - & - & - & - & - & - & - \\
$>6-12$ months & 34 & - & - & $34(11.26 \%$ & $1(2.94 \%)$ & - & $2(5.88 \%)$ & - & - \\
$>12$ months & 302 & $4(1.32 \%)$ & $2(0.66 \%)$ & $34(11.26 \%)$ & $3(0.99 \%)$ & $4(1.32 \%)$ & $17(5.63 \%)$ & $12(3.97 \%)$ & $17(4.84 \%)$ \\
Sex group & & & & & & & & & \\
Female & 171 & $1(0.58 \%)$ & - & $23(13.45 \%)$ & $2(1.17 \%)$ & $2(1.17 \%)$ & $13(7.60 \%)$ & $7(4.09 \%)$ & \\
Male & - & $3(1.66 \%)$ & - & $16(8.84 \%)$ & $2(1.10 \%)$ & $2(1.01 \%)$ & $6(3.31 \%)$ & $5(2.76 \%)$ & \\
Total & 352 & $4(1.14 \%)$ & $2(0.57 \%)$ & $39(11.08 \%)$ & $4(1.14 \%)$ & $4(1.14 \%)$ & $19(5.40 \%)$ & $12(3.41 \%)$ & $17(4.18 \%)$ \\
\hline
\end{tabular}

\section{DISCUSSION}

During this study, over all prevalence of 49 $\%$ endoparasites, $24 \%$ ectoparasites and $0.57 \%$ haemoparasite were registered. The prevalence of endoparasites recorded during this study is less than $54.38 \%$, reported by Dejenu (1998), in cattle in Kelala, South Wollo and $82.8 \%$, reported by Nesru (1998) (82.8\%) and 78.7\% by Endale (2006) in Holeta. One of the major parasitic problems in the study area was fasciolosis, which accounted for $23.30 \%$ of the positive samples during the survey. This result is similar to the report of Amanuel (1992), who reported a prevalence of $26.22 \%$ in Chilalo-Arsi. This could be due to similar ecological condition for the distribution of the snail intermediate hosts. There was no significant difference ( $\mathrm{P}>0.05$ ) observed in the prevalence of fasciolosis between the age groups and sexes.

Significant difference ( $\mathrm{P}=0.000$ ) in the prevalence of Toxocara vitolurum among the age groups was observed in this study. Higher prevalence was recorded in animals with the age of up to 6 months(37.50\%), followed by animals with the age of more than 6 to12 months(17.65\%) and the least figure was registered in animals above 12 months $(7.28 \%)$ old. This has a strong agreement with the report of Faris (2005) in Holeta. The higher prevalence of Toxocara vitulorum in caltte aged up to 6 months could be attrubuted to the fact that the most important source of infection is the milk of the dam in which larvae of the parasite are available for up to 30 days after parturition and calves are hence exposed to the infection. The ingestion of larvated eggs by calves over six month old seldom results in potency (Urquhart et al., 1996. In female animals resumption of development in late pregnancy allows further transmammary transmission (Urquhart et al., 1996). Other helminthes like strongyles ( $4.83 \%$ ), Paraphistomum cervi ( 9.38\%), Monesia benedeni ( $0.85 \%)$ and also the haemoparasite, Babesia bovis ( $0.57 \%$ ) were identified in this study. Other workers : (Faris, 2005, Etsehiwot, 2004, Tesfaye, 1998) have also reported similar findings on the prevalence of these parasites in different parts of the country. During this study major ectoparasites identified include Linognathus vituli (11.08\%), Amblyomma varigatum (5.40\%), psoroptes bovis (1.14\%) and Sarcoptes scabiei (0.57\%). Even though detailed studies on the distribution of ectoparasites of cattle were not conducted in the country, some workers have reported the existence of different tick species from various parts of Ethiopia (Mehari, 2004, Surafel, 1996, Dejenu, 1998, Yitbarek, 2004, Mekonen et al., 2000, Endale, 2006).

The present findings of sarcoptas and psoroptas have strong similarity with that of Yacob et al., (2008) who reported $0.34 \%$ and $0.68 \%$ prevalence respectively in Adama. The current results on the prevalence of linognathus, Heamatopinus, psoroptes and sarcoptes are similar to an earlier report from eastern Shoa (Amanuel, 1992). There was no significant variation ( $P$ $>0.05$ ) in the prevalence of ectoparasites 
among age groups and sexes.

During mortem examination of cattle at Ambo municipal abattoir, the dominant endoparsites observed were Hydatid cyst (22.22\%), paraphistomum cervi (15.15\% ) and Fasciola hepatica ( $11.11 \%)$. Similar results $(21.13 \%$ and $25.7 \%)$ on the prevalence of Hydatid cyst were reported by Graber (1975) in Addis Ababa and Konso respectively.

\section{CONCLUSION}

The prevalence of different endoparasites and ectoparasites observed in rular cattle in the study area indicate that the area is conducive for the successive perpeptuation of theses parasites and favourable for subsequent transmission to susceptible hosts. The significance of these parasites should not be underestimated as they hamper the growth, productivity and reproductive potential of animals and inflicting skin damage resulting in economic loss of the individual farmers in particular and the nation in general.

\section{ACKNOWLEDGMENTS}

The author would like to thank the staff members of Ambo Veterinary clinic and abattoir for their keen support during sample collection, processing and laboratory examinations.

\section{REFERENCES}

ADEME, Z. (1985) : Importance of helminthiasis in the cheffa dairy farms, South wollo,DVM thesis, Faculty of Veterinary Medicine, Addis Ababa University.

AMANUEL, K. (1992): Ectoparasitosis and associated skin disease of Cattle in some selected areas of eastern shoa, DVM thesis,Faculty of Veterinary Medicine, Addis Ababa University

CSA (2004) :Ethiopian Agricultural Sample Enumeration, 2001/ 2002. Central Statistic Authority; Federal Democratic republic of Ethiopia.

DEJENU, G. (1998) : A preliminary survey of ticks on domestic animals in Bale Administrative region, DVM thesis, Faculty of Veterinary Medicine, Addis
Ababa University

ENDALE, B.(2006): A survey on ticks of cattle in Ambo area, west shoa, DVM thesis, Faculty of Veterinary Medicine, Addis Ababa University

ETSEHIWOT W. (2004) : A study on bovine GIT helmithes in dairy cows in and around Holeta, Faculty of Veterinary Medicine, Addis Ababa University.

EYSKER, M., PLOEGER, H.W. (2000): Value of present diagnostic tests for GIT nematodes infection in ruminants. Division of parasitology and tropical veterinary medicine, utherechet University, the Netherlands, 109- 116

FARIS, D. (2005): Study on endo and ecto parasites of young cattle in Holeta and its surroundings, DVM thesis, Faculty of Veterinary Medicine, Addis Ababa University.

GRABBER, M. (1975) : Helminthes and helminthiasis of domestic and wild Animals in Ethiopia, Ministry of Agriculture, Addis Ababa, Ethiopia, 8290

IBRAHIM, H., OLALOKU E.(2000) : Improving cattle for milk, meat and traction ILRI (international livestock research institute), Manual 4, Nairobi, Kenya, 135.

MEHARI, B. (2004) : Distribution of livestock tick species in Awassa area, DVM thesis, Faculty of Veterinary Medicine, Addis Ababa University

MEKKONNEN, S., HUSSILEN, I., BEDANE, B. (2000):The distribution of ixodid ticks in centeral Ethiopia, onderstepoort Journal of Vererinary Research, 68: 243-252.

NESRU, H.M. (1998) : Study on calf mortality of Adami Tulu Research Center In : Procedings of 5th conference of ESAP ( Ethiopan Society of Animal production) Addis Ababa, Ethiopia.

SOULSBY, E.J.L. (1986): Helminthes, Arthropods and protozoa of Domestic animals, $7^{\text {th }}$ ed., Baillier Tindal, 136346

SURAFEL, M. (1996) : Survey on tick species in four domestic animals in Tigray region, DVM thesis, Faculty of Veterinary Medicine, Addis Ababa University. 
TESFAYE, H(1998): Ovine \& Bovine Helminthiosis in Kelala, South Wollo. In proceedings of Ethiopian Veterinary Associatione, Addis Ababa, Ethiopia, 30

TIZARD, I.B. (1996): Veterinary immunology . An Introduction; Immune response of new borne animals, $5^{\text {th }}$ ed, Department of pathology, the Texas veterinary medicine center, Texas A\&M University, College Station, Texas, 241250

URQUHART, G.M., ARMOURT, DUNCAN, J.L., DUNN, A.M., JENNINGS, F.W.(1996) : Veterinary parasitology, $2^{\text {nd }}$ ed. Blackwell Science Ltd. London, UK, 229-301

WORLD BANK ( 2001): Livestock development report, World Bank,
Washington DC, USA.

YACOB H.T., NETSANET, B. DINKA A. (2008) : Prevalences of major skin diseases of cattle, sheep and Goats in Adama veterinary clinic, Oromia regional state, Ethiopia, Review med vet., 159: 455-461.

YITBAREK, G. (2004): Tick species infesting livestock in Jimma area, South West Ethiopia, DVM thesis, Faculty of Veterinary Medicine, Addis Ababa University.

ZERFU, M. (1991): Prevalence of GIT helminthes of cattle in Chilalo Awraja, Arsi administration, DVM thesis, Faculty of Veterinary Medicine, Addis Ababa University. 